\title{
A STUDY ON THE CUSTOMER'S ACCEPTANCE TOWARDS ISLAMIC BANKING PRODUCTS AMONG NON-MUSLIM IN DUAL BANKING SYSTEM
}

\author{
JUWAIRIAH MOHAMAD \\ MUHAMMAD FAKHIRIN CHE MAJID \\ Islamic Business School \\ Universiti Utara Malaysia
}

\begin{abstract}
Islamic banking products (IBP) are offered not only to the Muslim community, but also to communities of other religions who are free to choose products depending on their convenience. According to a report, the percentage of non-Muslim communities choosing IBP in Malaysia has been steadily increasing and is expected to continue to increase in future. The Dual Banking System is one of the initiatives that has been created in conventional banks as an extra facility for the communities to engage with IBP easily without going to Islamic Banks. This paper aims to study the factors that drive non-Muslim customers to accept IBP. Specifically, this paper examines the relationship between four factors: knowledge, understanding, perception and the level of awareness among non-Muslim customers regarding their acceptance on IBP in the Dual Banking System. About 140 non-Muslim IBP customers of the Dual Banking System around Changlun, Jitra and Alor Setar were selected based on convenience and were randomly picked as respondents of this study. Some data were also collected through interviews with the bank personnel and the bank's customers besides the self-administered questionnaire survey. Employing the SPSS approach, the hypotheses of the study were tested. The findings showed that there are significance relationships between customer's knowledge, understanding, positive perception, and the level of awareness perceived among non-Muslim customers and their acceptance of IBP.
\end{abstract}

Keywords: Islamic banking products; non-Muslim customers; acceptance. 
IJMS 23 (1), 1-11 (2016)

\section{Introduction}

In Malaysia, customer's positive perception of Islamic banking is far more crucial mainly due to the fact that Islamic banks have to compete with the long established conventional banks in the dual banking system (Dusuki, 2007). The parallel operation of the Islamic banking system and the conventional system as well as the products offered are quite similar to each other. However, they create a new situation where the level of consumers' satisfaction has to influence the success of an Islamic bank to attract potential customers among the non-Muslims (Doraisamy, Shanmugam \& Raman, 2011).

Since religion is no longer the main factor in attracting customers, Islamic banks should recognize that customers view them just like any other commercial bank (Haron et al., 1994). As supported by Doraisamy et al. (2011) and Amin, Rahim, Laison \& Magdalene (2011), profitability, quality of service, attitude of the consumers, and social influence are among the important factors to attract customers to accept the Islamic banking products. This situation shows that the management team of Islamic banks should realize and also acknowledge that the banks can no longer depend on Muslims as their base source of depositors or as their fund users. The Islamic banks have to adapt new strategies to expand their customer base by including non-Muslims as potential customers.

Dr. Zeti Akhtar Aziz, the Governor of the Central Bank of Malaysia, in her speech at the Malaysian Banking and Financial Services Summit 2002, stated that Islamic Banking in Malaysia is now at the threshold of entering its next stage of development, to expand on a global basis, to gain greater acceptance as an effective and efficient means of intermediation and to contribute to overall wealth creation.

Hamid and Nordin (2001) found out that most of the customers had poor understanding of the differences between Islamic and conventional banking. The customers also had limited knowledge of Islamic banking. The lack of knowledge about Islamic banking would affect the acceptance of the Islamic banking products. In fact, the study carried out by Abdullah, Sidek and Adnan (2012) revealed that a better knowledge and understanding possessed by non-Muslims will increase the acceptance of the Islamic banking products. 
Presently there are many Islamic Banks such as Bank Islam, Bank Muamalat, RHB Islamic Bank and commercial banks that are offering the same Islamic Banking products in Malaysia, but a few problems arise especially in product knowledge, understanding the terms and the product features. The customers are confused about the principles such as Mudarabah, Bai-Muazzal, Ijarah, Istisna, Bai-Salam and others used in Islamic banking.

So, this study aims to know the level of customers' acceptance of IBP that are offered by the Dual Banking system among the non-Muslims and the relationship between acceptance and the four other factors such as knowledge, understanding, perception and awareness.

\section{Literature Review}

\section{Preliminary Research: Criteria of Choosing Islamic Banking Products}

A number of studies have been carried out about the criteria for the selection of either specifically Islamic banking products or Islamic banks in general in Malaysia as well as in different countries.

In the study of the perception of the non-Muslim customers of the Islamic banks in Malaysia, Abdullah et. al (2012) reveal that the Islamic banking services are in the right path to attract non-Muslim customers in Kuala Lumpur. In fact, the respondents believe that in the near future, Islamic banking would take over conventional banking in Malaysia. Information availability, understanding, and awareness have to be addressed as important elements for Islamic banks to take into account to attract and educate the consumers. However, the study only focused in Kuala Lumpur.

Bley, et. al (2011) examined the reasons for consumers to select Islamic banking services rather than conventional banking services by using self-administered questionnaires in Sungai Petani, Kedah. From the data analysed by SPSS, tool V.13 package, the findings showed that the customers were aware of the existence of the Islamic banking services and they preferred them because of the profitability and quality. However, there was a lack of further research throughout the state. 
Bley and Kuehn (2004), examined the relationship between the knowledge of the financial concepts (conventional and Islamic), the preference for either conventional or Islamic financial services, and certain individual characteristics of the raters. One of the driving motivations for this study was the belief that the lack of knowledge of specific Islamic products was in part attributable to the Arabic vocabulary used to identify Islamic financial products. Most of the world is not even minimally fluent in Arabic, and this is true in the Muslim world as well. The use of Arabic hinders the understanding of what these Islamic products really are. Furthermore, due to the relative newness of the products offered, the market is generally ignorant of these products.

Jorg et al. pointed out that the poor knowledge of Islamic finance principles has been one area of concern in this literature for over ten years (Omer, 1992). Besides the increase in the number of Islamic banking terms has been considerable over this period. Additionally, in spite of the growing interest in the field of Islamic finance, a high level of awareness of the Islamic banks (Haron et al., 1994) and the growing interest in the use of Islamic banks (Al-Ahmed, 1996), no general educational initiative has been launched by either the government or the financial institutions (Hamid \& Nordin, 2001) to address this lack of basic product knowledge.

The strong growth in the Islamic financial service sector suggests that a greater understanding of the factors that influence these choices can only benefit the development of appropriate strategies to address the growing appetite for these products and services (Ahmad \& Haron, 2002). While, according to Gerrard and Cunningham (1997), a lack of understanding became the driving factor for the absence of awareness. A study conducted in Singapore showed that most of the customers did not understand the meaning of Shari'ah principles and no one could explain the meaning of Murabahah, precisely.

Ahasanul, Osman and Ismail et al. (2009) identified that customer perception about IBP is influenced significantly by the quality of services, confidence in the bank, social and religion perspectives and the availability of services. Three coefficients were positive values showing that there were positive relationships between customer perception and quality of services, social and religious perspective and availability of services. In other words, the positive values of the coefficient revealed a positive perception of Islamic banking. 
Furthermore, the higher level of availability of services and social and religious perspectives made IBP easier and comfortable. It showed that customer's perception could mediate the effects of bank service quality on performance. Customer perception and satisfaction can be considered as the keys to the bank's overall performance.

As for this research, the research model was adopted from previous research of Hamid and Nordin (2001) who surveyed Malaysian commercial bank customers. They found a poor understanding of the differences between Islamic and conventional banking. Ahmad \& Haron (2002), studied the Malaysian Corporate customers' knowledge of Islamic banking products and services, and then noted that the respondents admitted to having a limited knowledge of Islamic banking products. Meanwhile, many researches about acceptance have provided important insights in explaining the success or failure of new products or services (Silberer \& Wohlfahrt, 2001;) and Bauer, Barnes, Reichardt, and Neumann, 2005).

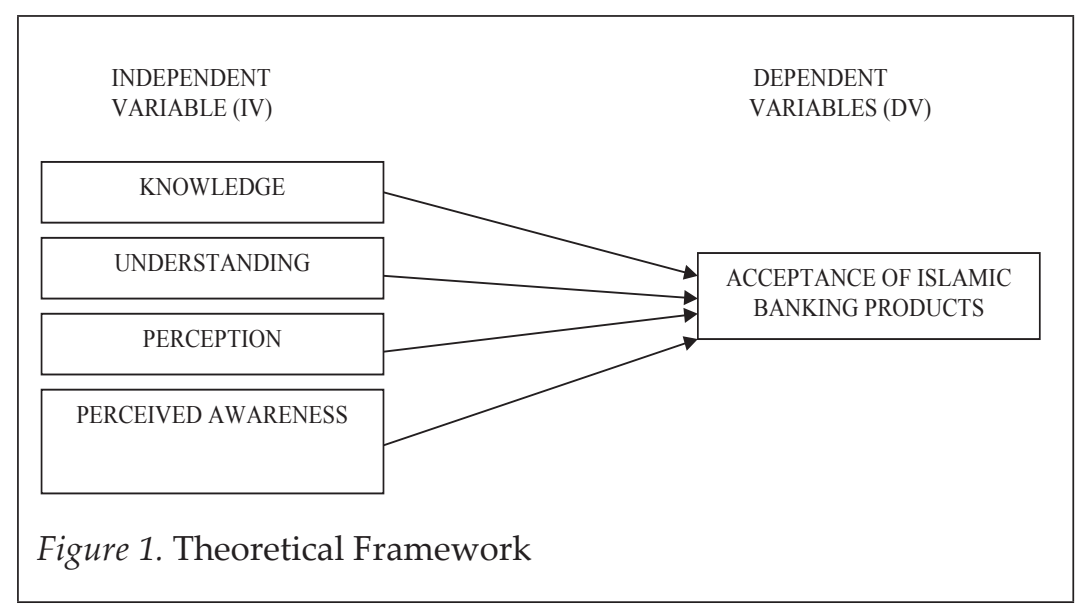

The model shows that four independent variables were chosen to test their relationships with customers' acceptance of the Islamic banking products. With this review, this study investigated the relationship between the four factors customer's knowledge, understanding, perception, and perceived awareness and customer's acceptance of IBP. Based on that four hypotheses were tested:

H1: There is a significant relationship between non-Muslim customers' knowledge of IBP terms and concepts and the acceptance of IBP. 
IJMS 23 (1), 1-11 (2016)

H2: There is a significant relationship between non-Muslim customers' understanding of the IBP terms and concepts and the acceptance of IBP.

H3: There is a significant relationship between non-Muslim customers' positive perception of IBP and the acceptance of IBP.

H4: There is a significant relationship between non-Muslim customers' levels of perceived awareness of the existence of IBP and the acceptance of IBP.

\section{Methodology}

For data collecting purposes, questionnaires were distributed to 200 non-Muslim customers who had opened accounts with the Islamic Window services offered by four conventional banks in Changlun, Jitra and Alor Setar. The banks were Maybank, CIMB, RHB, and EON Bank. The questionnaires were constructed based on past researches that are related with this research. The questions used a five point Likert Scale, ranging from five "strongly agree" to one "strongly disagree". The questionnaires were divided into six sections consisting of 29 questions. Questions in Section A were about demography, while the questions in Sections B, C, D, E, and F covered on customers' knowledge, understanding, perception, awareness, and customers' acceptance of Islamic banking products. The questionnaire had a reliability level, expressed as Cronbach's alpha of 0.6 and above, which can be recognized as acceptable.

The sample selection was based on convenience and these customers were randomly picked. Every non-Muslim customer that came to make their bank transaction was chosen to answer the questionnaire. This process ran for three weeks. Of the 200 of questionnaires distributed, only 140 were returned and were acceptable for the study. According to Sekaran (2003), 132 out of a population of 200, were acceptable as respondents.

The data collected for the study was analyzed by using the SPSS in order to test the significant level of the hypotheses. The Pearson Correlation Test was used. All the hypotheses were tested to determine whether there was a relationship or not between the dependent variables (acceptance) and the four independent variables (knowledge, understanding, perception, and customer awareness) 


\section{Results}

The profile data of the 140 respondents collected consisted of gender, religion, age, marital status, and education level. The data below will explain the demographic criteria of the respondents who were engaged in the Dual Banking System which was offered by the conventional banks around Changlun, Jitra and Alor Setar.

Table 1 shows that there were (54\%) female respondents and (46\%) male respondents. The second criteria was religion. $43 \%$ (61) of the respondent were is Buddhist, $40 \%$ (56) were Hindus, 16\% (22) were Christians and $1 \%$ were other religions. The questionnaire not include Islam because the research focused on non-Muslim customers only. According to the interview with the bank staff, the majority of the Buddhist customers were Chinese and worked as businessmen. The third criteria was age. The majority of the respondents were under 25 years old. This was followed by the age range of 25 to 39 years old (28\%) and 40 to 55 years old (9\%). As for marital status, $70 \%$ of the respondents were single and 30\% were married. The last criterion was education level. Most of the respondents had degree.

Table 1

Frequency Demographic Criteria Analysis of Respondents

\begin{tabular}{lcc}
\hline \multicolumn{1}{c}{ Criteria } & $\mathrm{N}$ & $\%$ \\
\hline Gender & 65 & 46.4 \\
Male & 75 & 53.6 \\
Female & & \\
& & \\
Religion & 61 & 43.6 \\
Buddhists & 56 & 40.0 \\
Hindus & 22 & 15.7 \\
Christians & 1 & 0.7 \\
Others & & \\
& & \\
Age & 88 & 62.9 \\
Under 25 years & 39 & 27.9 \\
25 to 39 years & 13 & (continued) \\
40 to 55 years & &
\end{tabular}


IJMS 23 (1), 1-11 (2016)

\begin{tabular}{lcc}
\hline \multicolumn{1}{c}{ Criteria } & $\mathrm{N}$ & $\%$ \\
\hline Marital status & 98 & \\
Single & 42 & 70.0 \\
Married & 0 & 30.0 \\
Divorced & & 0.00 \\
& & \\
Education level & 14 & \\
Master's Degree & 79 & 10.0 \\
Degree & 15 & 56.4 \\
Diploma & 32 & 10.7 \\
Certificate & 0 & 22.9 \\
Other & & 0.00 \\
\hline
\end{tabular}

The Pearson Correlation analysis was used to test the four hypotheses. The four independent variables were knowledge, understanding, perception and awareness, meanwhile the dependent variable was customers' acceptance of IBP. The result shows that the all hypothesis are accepted. There are significant relationships between the four independent variables and the customers' acceptance of IBP. Table 2 shows the results of the Pearson Correlation analysis.

Table 2

Results of the Pearson Correlation analysis

\begin{tabular}{|c|c|c|c|c|c|c|}
\hline & & Acceptance & Awareness & Knowledge & Understanding & Perception \\
\hline \multirow[t]{3}{*}{ Acceptance } & Pearson Correlation & 1 & $.435^{* *}$ & $.553^{* *}$ & $.380^{* *}$ & $.597^{* *}$ \\
\hline & Sig. (2-tailed) & & .000 & .000 & .000 & .000 \\
\hline & $\mathrm{N}$ & 140 & 140 & 140 & 140 & 140 \\
\hline \multirow[t]{3}{*}{ Awareness } & Pearson Correlation & $.435^{* *}$ & 1 & $.491^{* *}$ & $.551^{* *}$ & $.520^{* *}$ \\
\hline & Sig. (2-tailed) & .000 & & .000 & .000 & .000 \\
\hline & $\mathrm{N}$ & 140 & 140 & 140 & 140 & 140 \\
\hline \multirow[t]{3}{*}{ Knowledge } & Pearson Correlation & $.553^{* *}$ & $.491^{* *}$ & 1 & $.509^{* *}$ & $.555^{* *}$ \\
\hline & Sig. (2-tailed) & .000 & .000 & & .000 & .000 \\
\hline & $\mathrm{N}$ & 140 & 140 & 140 & 140 & 140 \\
\hline \multirow[t]{3}{*}{ Understanding } & Pearson Correlation & $.380^{* *}$ & $.551^{* *}$ & $.509^{* *}$ & 1 & $.582^{2 * *}$ \\
\hline & Sig. (2-tailed) & .000 & .000 & .000 & & .000 \\
\hline & $\mathrm{N}$ & 140 & 140 & 140 & 140 & 140 \\
\hline \multirow[t]{3}{*}{ Perception } & Pearson Correlation & $.597^{* *}$ & $.520^{* *}$ & $.555^{* *}$ & $.582^{* *}$ & 1 \\
\hline & Sig. (2-tailed) & .000 & .000 & .000 & .000 & \\
\hline & $\mathrm{N}$ & 140 & 140 & 140 & 140 & 140 \\
\hline
\end{tabular}


Based on the analysis, the positive perception among non-Muslim customers of IBP has the highest correlation with customer's acceptance of IBP in the Dual Banking System (0.597), followed by knowledge (0.553), perceived awareness (0.435) and understanding (0.380). The finding showed that all hypotheses are supported. The analysis also found that the positive perception among non-Muslim customers of IBP is the critical factor that drives customer's acceptance of IBP in the Dual Banking System, followed by customer's knowledge, perceived awareness and understanding.

\section{Discussion, Limitations and Recommendations}

Most of the non-Muslim customers accept the IBP because of their positive perception of the IBP. Most of them have good perceptions of the IBP either for the short term or for the future. They believe these products will be able to survive due to the aggressive growth that can be seen today compared with the beginning of the IBP in Malaysia, which they only offered a few products and services.

Non-Muslim customers also have high knowledge of IBP especially in Malaysia. Some respondents said that they know about the existence of IBP in Malaysia and most of them also knew that the principles of IBP and the services are different from the conventional banking system. Most of the respondents in this research had been engaged with IBP and the services for more than five years and they also knew the name of the banks that offered IBP not only local banks, but also foreign banks. The knowledge was gathered not only from formal learning but also in an informal way. Not all customers have a high level of education. They got the information about IBP and the services from their reading, promotion from the staff of the banks and also from friends that were engaged with IBP and the services.

Although awareness and understanding of IBP and the services are considered low among the non-Muslim customers, these factors were also listed as the factors in accepting IBP and the services. Most of the non-Muslim customers have less understanding of the IBP principles but they understood the names of the services that were provided by the banks such as deposit account, financing and so on and so forth. They reported that it was difficult to remember and memorize the principles like al-Musyarakah, and al-Mudharabah. Some of them knew how the principle operated, but often use the terms, once in a while. 
The small scope of this study could be revised in the future. Nowadays, there are many additional factors that drive non-Muslim customers to engage with Islamic banking products. For future research, some recommendation are suggested. Improvise the content of the study and expand the study to include more independent variables. Previous studies had been shown that there were many factors that influence non-Muslim customers to patronize Islamic Banking System. The future researcher should try to test how critical that factors are in influencing customers to accept IBP and the services. This type of research is very important to the industrial sector as information for them to develop new Islamic products according to customers' needs and perceptions. This information could also lead the marketing department on to develop their marketing strategy. Last but not least, management teams also can review the level of customers' acceptance of the Islamic banking products nowadays.

\section{References}

Abdullah, A. A., Sidek, R., \& Adnan, A. A. (2012). Perception of nonMuslim customers on Islamic banks in Malaysia. International Journal of Business and Social Science, 3(11), 151-163.

Ahasanul, H., Osman, J., \& Ismail. Z., (2009). Factors influencing selection of Islamic banking : A study on Malaysian customer preferences. American Journal of Applied Sciences, 6(5), 922-928.

Ahmad, N., \& Haron, S. (2002). Perceptions of Malaysian corporate customers on Islamic banking products and services. International Journal of Islamic Financial Services, 3(4), 13-29.

Al-Ahmed, A.Y. (1996). The Islamic financial instruments utilisation, M.Sc. Dissertation, Loughborough University, 1996.

Amin, H., Rahim Abdul Rahman, A., Laison Sondoh Jr, S., \& Magdalene Chooi Hwa, A. (2011). Determinants of customers' intention to use Islamic personal financing: The case of Malaysian Islamic banks. Journal of Islamic Accounting and Business Research, 2(1), $22-42$.

Bauer, H. H., Barnes, S. J., Reichardt, T., \& Neumann, M. M. (2005). Driving consumer acceptance of mobile marketing: A theoretical framework and empirical study. Journal Of Electronic Commerce Research, 6(3), 181-192.

Bley, J., \& Kuehn, K. (2004). Conventional versus Islamic finance: Student knowledge and perception in the United Arab Emirates. International Journal of Islamic Financial Services, 5(4), Retrieved December 24,2010, from http://islamic-finance. net/journals/ journal20/vol5no4art2.pdf. 
Doraisamy, B., Shanmugam, A., \& Raman, R. (2011). A study on consumers' preferences of Islamic banking products and services in Sungai Petani. Academic Research International, 1(3), 290-302.

Dusuki, A., \& Abdullah, N. (2007). Why do Malaysian customers patronize Islamic Banks? International Journal on Bank Marketing. 25(3) : 142-160

Erol, C., \& El-Bdour, R. (1989), Attitude, behavior and patronage factors of bank customers of Islamic Banks, International Journal of Banking Marketing, 7(6), 31-9.

Erol, C., Kaynak, E., \& El-Bdour, R. (1990), Conventional and Islamic Bank: Patronage behavior of Jordanian customers, International Journal of Banking Marketing, 8(5), 25-35.

Gerrard, \& Cunningham, J. (1997). Islamic banking: A study in Singapore. International Journal of Bank Marketing, 15(6), 204216.

Hamid, A., \& Nordin, N. (2001). A study on Islamic banking education and strategy for the new millennium-Malaysian experience. International Journal of Islamic Financial Services, 2(4), 3-11.

Haron, S., Ahmad, N., \& Planisek, S. (1994), Bank patronage factors of Muslim and non-Muslim customers, International Journal of Bank Marketing, 12(1), 32-40.

Haron, S., \& Ahmad, N., (2002). Perception of Malaysian corporate customers of Islamic banking products and services, International Journal of Islamic Finance Services, 3(4).

Obaidullah, M. (2005). Rating of Islamic financial institutions: Some methodological suggestions. King Abdul Aziz University, Jeddah. Saudi Arabia. Scence Publishing Centre.

Omer, H.S.H. (1992). The implications of Islamic beliefs and practice on the Islamic financial institutions in the UK. Ph.D. Dissertation. Loughborough University, 1992.

Rammal, H.,\& Zurbruegg, R.(2007). Awareness of Islamic banking products among Muslims: The case of Australia. Journal of Financial services marketing. 12(1), 65-74.

Silberer, G., \& Wohlfahrt, J. (2001). Akzeptanz und Wirkungen des Mobile Banking. Strategien im M-Commerce, Stuttgart, 161-176.

Uma Sekaran. (2003). Research method for business: A skill building approach. (4th Ed), John Wiley \& Sons. 